\title{
IDEOLOGY AND THE DE/NATURALIZATION OF MEANING IN THE CAMEROONIAN NOVEL
}

\author{
Emmanuel YEWAH \\ Department of Foreign Languages \\ Albion College \\ Albion Michigan, 49224 \\ USA
}

CURRENT RESEARCH INTEREST: Politics and law in African literature

\section{SUMMARY}

This article shifts the focus of the study of ideology from the question "what is ideology?" to how it is produced and reproduced. It deals with the process by which social subjects/characters, i.e., the dominant class and the subjugated, participate, through their interactions in the network of relationships, in the production and reproduction of ideologies and meanings once they have become educated, through their experiences and by other social activists, of their subjugating effects.

KEY WORDS: (re)production, meaning, text 
An ideology is dynamic and a force, always resilient always keeping itself in some consonance and unity, but not always the same consonance and unity

Mc Gee, The 'Ideograph': A Link between Rhetoric and Ideology

Cameroonian written literature, as a growing number of national literatures in Africa today, has gone through different phases. One phase, as Claire Dehon has described very aptly, is that of litterature artisanale. That is the kind of literature in which art and society are one, or in which songs, praise poems and folktales arise from preoccupations, beliefs, assumptions and struggles of the community as a whole and are not regarded as creations of particular individuals (Ngara, p. 21). Another phase emerges when such writers as Mongo Beti, Ferdinand Oyono use elements of oral traditions in their satirical, ironical or allegorical depictions of the colonial society and the post independent political structures.

Since the late seventies, however, a new generation of writers has emerged. They use a wide rage of devices in their words to explore political, social, economic and ethical issues. One such device is the use of animal imagery as in Les Chauvessouris (Naga, 1980), Les Puces (Ndongo, 1984). It is a literary device in the nature of caricature and allegory with a long history in both oral and written literatures all over the world. The phenomenon is so pervasive that dealing with two texts raises the question of selection. The texts under discussion here use the technique to make critical commentaries on the specific political and economic situations in post-colonial Cameroon. The new generation is using this technique to expose the corrupt nature of the present Cameroonian society. Corruption here is not intended to apply selectively to a specific class or a small privileged group but is meant as a generalized phenomenon, interwoven into the fabric of the society as a whole. In the texts in question, humans have been reduced metaphorically to the level of such repugnant creatures as lice and bats, in an attempt by the writers, to reveal a world in which ideological discourses are couched behind a seemingly benevolent rhetoric. In other words, the reduction of humans, especially those in positions of power (economic, political, etc.), to animals helps to unmask the kind of social conditioning or ideological assumptions that people have been made to internalize or naturalize. 
Ideology, James Kavangh writes, designates a rich 'system of representation' worked up in specific material practices, which help from individual into social subjects who freely 'internalize an appropriate picture' of their social world and their place in it (p. 310). In the texts, the social subjects are formed and portrayed through a network of relationships. In Les Chauves-souris, this social process that works on and through every social being, (p. 311) brings out not only class or group differences but also gender and generational differences; for example, Bilanga's relationship with his son Roger, the various women with whom he is involved including his wife, the villagers, and the pro-Marxist philosopher Biyidi. In all these relationships, Bilanga is portrayed as a rich, arrogant, manipulative, exploitative, corrupt, power-driven, materialistic, and voracious capitalist and all those he interpellates as exploited either sexually as the women or materially as the villagers.

Les Puces on its part creates a network of relationships to show how the classes or groups involved in that social process participate in some sort of market economy, that is, a system of exchange in which the labour of the workers and peasants as producers is exploited by the leaders of the Buyers'Union. It does this by falsifying the methods of quality control of cocoa and by manipulating the scales used to weigh it. For instance, textual evidence shows that even though the farmers follow strictly the guidelines laid down by the Union in preparing the cocoa for the market, the latter, upon examination of the produce, still ends up with such arbitrary decision as, cacao de mauvaise qualité! Mal séché! Deuxième grade! (p. 25) A decision that always draws the following reaction from the farmers: jamais un habitant de Nkolmeyok n'avait réussi à faire classer son cacao au grade de référence, le premier (p. 25). The Buyers' Union is able effectively carry out its exploitative agenda because, in this uneven power relationship of the educated buyers to the supposedly uneducated workers, the former has appropriated the knowledge of the working of the scales. They use their monopoly over knowledge and the means of achieving it à dérégler la balance de façon à gagner dix kilogrammes sur chaque sac [de cacao] pesé (p. 25). Nevertheless, in their struggle against the invasion of bugs, here symbolizing the corrupt Buyers' Union, the chief of the village and his European partners in crime, the villagers become conscious of their social conditioning.

Becoming conscious of the social process that they had naturalized in the form of traditions also leads to disillusionment (given the failure of such ideology or such traditional beliefs to cater for their basic needs), which in turn leads to a revolt against those ideological assumptions and in the process affect what I have called de-naturalization. By naturalization, I mean the process of unconscious internalization and expression of beliefs, values, ideas, perceptions and modes 
of thinking of a given society and class at a given period of time. Henceforth. I shall use the terms naturalization and internalization interchangeably.

Given that ideology is not... a static set of ideas through which we view the world, but a dynamic social practice, constantly in process, constantly reproducing itself in the ordinary workings of these apparatuses, (Fiske, p. 258) or that ideologies should be seen not as possessions or texts bus as ongoing social processes, (Therborn) the question, it would seem, is no longer that of defining ideology, since this has been dealt with extensively in world literatures. This study therefore shifts the focus from that rather belaboured question to a much more delicate question of how ideology is produced. That is, it is an analysis of the process by which ideologies or meanings are produced and reproduced in the interaction between the dominant class and other social subjects in a given society at a given period of time. It will also be concerned with how, in that dynamic social practice, in that process, an individual or a whole community of the subjugated is socially, culturally and politically conditioned to naturalize a given system of representation.

Additionally, It will show how the characters in the texts attempt to de-naturalize or empty-out those meaning once they have become educated, through their own experiences and by social activists as Biyidi, Roger, and Koulou in the kinds of corrupt behaviour that are camouflaged behind ideological discourses. As this penetrating look into the mind of Roger reveals, Roger semblait de plus en plus prendre le chemin d'une révolte intransigeante, parlait de l'exploitation cynique des pays pauvres par les pays riches, qui se servaient copieusement par personnes interposées. Il fustigeait la corruption et la couardise des nouvelles élites du pays, qu'il traitait de complices du système capitaliste. He adds that les indépendances africaines étaient des indépendances-bidon qui ne profitaient qu'à quelques-uns (p. 83). He declares in conclusion that official speeches are empty sounds that do not provide any relief for the masses.

Roger's comments above are directed to his father Bilanga, who serves as a middleman in the European powers exploitative set up. Like M. Chauvin, the businessman, and other exploiters in the text, he is reduced metaphorically to a chauve-souris in an attempt to unmask the hypocrisy behind his seeming benevolence to his people. As Marie, one of his mistresses, remarks quite appropriately, Bilanga ne faisait rien gratuitement (p. 30). Reducing humans to bats or creatures that do not fit into one specific classification of species such as mammal or bird is symbolic of the kind of double personality that those humans have acquired. One of those personalities incarnates the dominant ideology of society, far removed from his people, yet with a supposedly benevolent side of him that contribute to his image of a savoir. For instance, he is shown throwing 
candies and money to the villagers from his car window whenever he visits his village. Their fluid personalities are also symbolic of the double message that their rhetoric and actions convey.

David Ndachi-Tangne's study Roman et réalités camerounaises provides a useful foundation for a discussion of ideology in the Cameroonian novel. His Study gives an overview of roman d'expression idéologique (p. 191) from 1960 to 1985. It does identify such ideologies as le mysticisme africain, le pragmatisme communautaire, le féminisme, and la philosophie du néant. But while such categorization or grouping is useful to students and scholars of African literatures as it offers them broad categories that could be used as bases of a more specific and detailed study of one more of those ideologies, the discussions do not read into what Boris Uspensky calls the ideological plane or the deep compositional structure (p.8). An ideological reading will attempt to show the process by which narrators, characters and other textual elements are conditioned to naturalize those various ideologies that the text delineates. One might ask at this point what skills are required to read into the subtext or the deep structure in order to decode the message underneath. In both texts, the tone, the utterances of various characters, the narrative voices' comments on other characters, the vocabulary, indeed, their form reveal a certain attitude towards the main characters or a class as represented by the Buyers' Union and what they stand for, that is, their values or lack of it.

Furthermore, and as Jonathan Culler has stated, to read a text as literature is not make one's mind a tabula rasa and approach it without preconceptions; one must bring to it an implicit understanding of the operations of the literary discourse which tells one what to look for (p. 113-4). In other words, beyond the surface or linguistic cues just referred to, each informed reader brings to the reading process an array of competences: cultural, historical, political, literary etc. Those competences allow him/her to read between the lines and also to understand how the texts' social subjects translate into action the implied author's abstract ideas and thus participate in the process of production and reproduction of ideology. For, as Rachel Blau Duplessis has noted, narrative in the most general terms is a version of, or a special expression of ideology: representations by which we construct and accept values and institutions. Any fiction, she adds, expresses ideology $(\mathrm{X})$.

While Ndachi-Tagne develops the various ideologies, above, from a wide range of texts, Zacharie Nzepa's essay on idéologie et forme focuses on two Cameroonian novels: Les Chauves-souris and Et sur la terre en passant (Evembe, 1966). He argues, somewhat convincingly, that ideology in those texts is expressed both 
through their form and their content. As he writes, les problemes actuels, traités par les écrivains, révèlent un contenu idéologique qui a une incidence directe sur l'esthétique des oeuvres. Autant dire que l'idéologique peut entretenir des rapports étroits avec la forme esthétique(p. 143-4). Using as reference Les Chauvessouris Nzepa identifies a dominant ideology of those who hold, in the words of Frantz Fanon, l'ensemble des pouvoirs économiques et politiques au mépris de la totalité nationale (p. 70).

Nzepa notes and aptly so that Bilanga, one of the protagonists, a fonctionnaire and a businessman, embodies the ideology of the dominant class. He describes members of that class as les hauts dignitaires de la lourde machine administrative, cette superstructure bureaucratique. In the words of Ambroise Kom, bilanga est le type même des nouveaux-riches de la bourgeoisie néo-coloniale (p. 95). The value system of those nouveaux-riches is based on the illegal acquisition of material wealth and the arrogant display of such wealth in the form of $l a$ construction d'immeubles. l'achat des véhicules de luxe, l'approvisionnement des comptes dans 'les banques africaines' [les banques européennes et americaines] (p. 146). More importantly, money as the base of this dominant ideology does not only serve to acquire wealth but also consciences les plus honnêtes et les plus désintéressées (p.131).

However, while Nzepa identifies all these various expressions of dominant ideology in the text at the phraseological level and shows how the text uses form - for instance his references to names of people and places - he fails to analyze the process by which the dominated are conditioned to naturalize that ideology. It should be noted that ideology is transcendent in that it has as much influence on the belief and behaviour of the ruler as on the ruled (McGee, p. 5). So even though his study is concerned with the process by which the dominated internalize meanings, the same process could apply to the dominant class that, even if it does not share the same moral and material values with the dominated, nevertheless, shares a common physical space.

In any society, the process of internalization starts with children since they do not have fixed ideas, attitudes, values, and perceptions nor actual modes of thinking... They do not yet discriminate among the myriads of meanings they are make to naturalize daily. It is, therefore, no wonder that children play an important role as subjects in the process of naturalization of ideology. They are formed as social subjects in their relationships, first in the context of what Louis Althusser calls the specific familial ideological configuration (p. 176) and than in schools where they are conditioned by the structure of the curriculum designed by an ideological state apparatus called the Ministry of Education. In Les Chauves- 
souris, the narrator states that pour les enfants, papa Bilanga semblait venir d'un autre monde, un monde different de celui des hommes (p. 41). The reference to Bilanga as papa by the children conveys both endearment and what their traditions expect of them, that is, respect for an older person. In addressing him as such, the children place Bilanga in the same age group as their own parents who are, indeed, role models for them. Through such utterances, they unconsciously identify with Bilanga as a role model whose values or lack of them they would emulate and celebrate. Moreover, by having children see him as coming from outside the world of humans, the text presents Bilanga as a mythic construct whose values (material wealth) they would internalize or naturalize as they grow up.

In The Ideology of Powers and the Power of Ideology, Gorän Therborn points out that ideology is the medium through which consciousness and meaningfulness operate; the consciousness of every new-born human being is formed through largely unconscious psychodynamic processes, and it functions in and through a symbolic order of language cades (p.2). Therefore, in our context here, the language used by the children to describe Bilange could be described as a psychosocially coded language that helps to produce and convey the dominant ideology and is, in itself, a product of that ideology. Since the personalities of those children are formed through their interactions and interpellations with other subjects, it is in this process that they unconsciously naturalize the language created by ideology; a language that, as noted above, is used in turn as a medium to articulate that ideology.

For the adults who may be of the same age or older than Bilanga and who are in a way trapped in a prison-house of coded language, the text presents Bilanga at a different conceptual level. He is no longer "papa" but is conceived as some higher being- - a Messiah. As the narrator reports, les adultes eux-mêmes au début, voyaient en Bilanga une sorte de messie tout puissant qui allait sauver Vémelé et tout le pays de la misère (p. 41). Presenting him at first as a messiah is indeed an attempt by the text to endow him with somewhat godlike qualities, such qualities that place him beyond the world of humans. In this way he becomes something they can only wish for but cannot attain. He fulfils their aspiration and his ideological assumptions are unconsciously celebrated. It should be pointed out that the use of au début in the passage above foreshadows the gradual shift from what might be called the villagers' collective unconscious to open revolt against Bilanga when they become conscious of the act that, as social subjects, their ideas and actions have been inscribed into the material ideological apparatus (p. 170) that he incarnates. A la fin, when the villagers, who are just as voracious as Bilanga, become aware of the fact that portraying the latter as a messiah as 
a generous man, is indeed a mask, they will start the process of unmasking, that is, of de-naturalizing Bilanga's values.

Bilanga's reversal of fortune comes from the fact that in the Cameroonian society, as in most African societies, one who has succeeded becomes some sort of messiah, a title that carries with it the burden of having to help his own people, his own village, overcome its misery. For as one of the Cameroonian sayings goes, when one of your own is up a plum tree, you eat the blackest, that is, the best plums. As a saviour of his own people, it becomes his sacred duty to be very generous with his fortune by sharing it with the villagers, who, it should be stressed, all lay claim the have played an important part in making hum what $\mathrm{s} / \mathrm{he}$ is today. Claire Dehon's comment on the Cameroonian society is relevant here. As she writes, dans la société camerounaise, un homme qui 'monte' à la capitale se doit de ne pas oublier son village. Un fonctionnaire aussi 'riche' et bien placé que lui [Bilana] se voit forcé d'aider matériellement ses parents et de favoriser le village de ses origines (p. 92). However, as a common stock and as stated above, the villagers are as voracious as Bilanga himself and demand more and more from him, le village n'est [jamais] satisfait, il veut toujours plus et il accuse le fonctionnaire d'avarice (p. 92).

Reducing all the characters to bats is the author's attempt to capture both Bilanga's avarice as he preys on his people and the villagers' avarice as they demand more on more from him. The text is indeed saying that even though Bilanga had preyed on his people through his seemingly benevolent gestures, he needed to hide behind such ideological rhetoric in order to protect himself from the incessant demands of the villagers. The fact that the villagers, having naturalized the idea that a successful son or daughter of the village has the moral responsibility, as dictated by tradition, to help everyone, even at the expense of his/her own needs, helps to set up a situation in which ideology and its manipulation by both sides becomes a central issue.

It is also said that when Bilanga came to the village, he would distribute des bonbons aux enfants, des cadeaux lors d'occasions spéciales, de l'argent à sa mère (p. 62). He would distribute paquets de cigarettes, de pleines bouteilles de rhum et de gin, des colis..., toutes les bonnes choses que les grands hommes de la ville pouvaient seuls payer(p. 44) to the older people. The portrayal of Bilanga as a generous man is meant to boost his image, to fit his image of a messiah, of the son of the village who hold an important position in the capital. But because the objects he offers to the villagers are selected to fit exactly the kinds of objects offered to some African kings by white slave traffickers, the underlying message here is that Bilanga has, in a way, substituted himself for those European outsiders, 
that is the colonialist and the imperialist, as the exploiter. It follows that one must read in the pseudo-divine qualities attributed to him a certain irony meant to destroy him and by extension help to deconstruct the process of naturalization of the dominant ideology developed by neo-colonialist and imperialist satraps.

Such a process of deconstruction is evident in what Roger said earlier and in these critical words from Marie: Bilanga était un monstre d'égoisme, calculateur. Même ses gestes apparemment les plus spotanés cachaient quelque interêt ( $\mathrm{p}$. 30). This statement and the patterned reaction to the patterned strains of a social role (Sutton) of the villagers to Bilanga as the incarnation of dominant ideology helps the exile Bilanga from what a Carpenties would call the kingdom of earth and that of heaven, or, in the words of the narrator, to put him in la prison traditionnelle, (p. 187) en quarantaine (p. 188). As his mother warns him, Vémelé te condamne à la prison traditionnelle, la prison du pays, comme on dit... Les gens de Vémelé ont décidé qu'ils ne voulaient plus te voir. Ils ne te salueront plus, et personne à Vémelé ne t'adressera plus parole. J'ignore pour combien de temps (p. 64).

In that way Bilanga, presented as a pseudo-divine construct earlier, is slowly deflated by the villagers because he cannot possibly satisfy their insatiable guest. His failure to satisfy his people financially and morally lead to his condemnation by the beneficiaries in these biblical terms: la justice de Dieu attendait les mauvais riches tels que Bilanga. Il leur serait plus difficile d'entrer dans le royaume des cieux qu'à un chameau de paser par le trou d'une aiguille (p. 36). Borrowing a famous passage from the Bible to condemn Bilanga's adoration and substitution of material wealth for spiritual and moral riches seems to be an attempt by the villagers to lace themselves on a high moral ground. But ironically, and because of their voracity, they are jest as guilty of greed and have the same moral flaws for which they are condemning Bilanga. Placing themselves on that false moral high ground is an attempt to distance themselves from the ideology that Bilanga incarnates. In this type of revolt against Bilanga the villagers attempt to de-naturalize the unequal system of representation into which they have been socialized.

Kwame Nkrumah suggests the an ideology, even when it is revolutionary [as above], does not merely express the wish that a present social order should be abolished, as is the case with the dominant ideology that is being destroyed here. It seeks also the defend and maintain the new social order which it introduces (p. 58). Les Chauves-souris ends with the destruction of the dominant ideology as expressed quite aptly in this poorly written sign declaring the independence of the village of Vémelé from the rest of the country of Eborzel: isi cimanse la républike libre otonome et indépendante de Vémelé (p. 183). In the place of the 
dominant ideology represented by Bilanga, a new order had been introduced fitting what Nkrumah has described as African communalism. He explains that ideology as the social level in terms of institutions such as the clan, underlining the initial equality of all and the responsibility of many for one (p. 69). This kind of ideology, that appeals to collective consciousness, forms the basis of Valentine Ndongo's Les Puces.

Les Puces, as stated earlier, depicts une ville cruelle in the 80's. Nkolmeyo, a small village, has been invaded by les puces or bugs. In the struggle against what the narrator describes as le combat inégal, l'invasion des puces l'épidémie, community life is destroyed and there is a general atmosphere of helplessness and chaos. As the narrator describes the situation: les villageois cesserent de vivre en communauté avec leus animaux domestiques et les gens se rendirent plus régulièrement au marigot prendre leur bain(?). In spite of these attempt to rid themselves of the parasites, they had no relief. As he says, amis les puces n'en poursuivirent pas moins leur invasion. Elles chatouillaient et piquaient sans répit et toujours à contretemps. Elles logeaient dans la tête, sous l'aisselle, dans tout le corps dont elles n'épargnaient même plus les parties intimes. Les démangeaisons qu'elles provoquaient mettaient les villageois mal à l'aise (p. 48). Harassed by the parasites, the villagers decide to burn all their belonging: les gens mettaient le feu à leurs vêtements et à leurs chaussures, détruisaient leur literie et leurs oreillers, brâlaient leur lit et leur matelas. Des femmes allèrent même jusqu'à se débarrasser de leur ustensiles de cuisine en aluminium (p. 49).

The invasion places the villagers in a physical and psychological stat in which they have no other choice but to act, not individually but collectively as a community. It is in the process of common struggle that the villagers are offered a way of experiencing their world. In that process, they develop, naturalize, and express the kind of ideology that Ndachi-Tangne has called le pragmatisme communautaire. This new order, inspired by the need for immediate action, is as shift from the kind of heavily bureaucratic system that, even in cases of emergency such as the invasion by bugs, would still require the victims to follow la voie hiérachique et officielle (p. 54) to obtain any form of assistance. In the process of the struggle, the villagers become aware of government rhetoric but also that behind such rhetoric there is no action. They are indeed abandoned in their struggle.

The only person who is concerned about their plight and seeks aid for them from authorities in the capital is a young philosopher named Koulou. Incidentally Koulou is the Bulu (an ethnic group) word for tortoise, the folklore character who outwits the other animals by his clever ruses. In a society such as the one in question 
here, however where, in the words of Dehon, toute critique est vue comme une atteinte à l'intégrité du pays, où les nouvelles sont filtrées par une radio et une presse d'état, ou il n'y a pas de débats publics..., (p. 90) the intellectual is always seen as subversive and his/her actions are always consciously misinterpreted by political leadership. As such it comes as no surprise that Koulou is accused of using the invasion as a pretext to expose the laxity, the inefficiency of political authorities, to incite violence in the village and as a springboard to advance his own political and social agenda. In the words of the narrator, Koulou y était accusé entre autres griefs, de semer la subversion dans le village, de soulever les esprits, de les inciter à la violence et à la désobéissance...d'incitation à la violence,de corruption d'innocentes mentalités paysannes (p. 62, 79). He is accused of being a crypto-communiste, un révolutionnaire et un fou comme l'était tout bon philosophe ou socilogue(p. 65). After a sham trial, again characteristic of his oppressive and dictatorial society, Koulou is incarcerated. Sending Koulou to jail helps to galvanize the villagers' protest against the inaction of the government and starts the process of critical re-evaluation of their system.

By contrast to Les Chauves-souris, that starts from a dominant ideology and words slowly towards its destruction and the introduction of a communal ideology, Les Puces starts from a pragmatisme communautaire and ends with what seems to be a resurgence of a dominant ideology using as medium of control the repressive prison system. In that context, les puces are not bugs but could be read as an allegory of actual people, the gendarmes, the army and other micro-powers that together defend the dominant ideology that oppresses the masses in the guise of defending state institutions. As his statement clearly illustrates: Les villageois croyaient que les puces, apparues avec les Blancs qui les avaient amenées dans leurs malles, devaient aussi disparaître une fois les Blancs partis. Mais c'était sans compter avec la résistance des parasites. Le départ du Blanc ne signifiant pas forcément la disparition des puces. Elles restaient en témoignage de la continuité de la présence du Blanc. Les puces ne refaisaient donc pas surface, elles se manifestaient tout simplement au grand jour (p. 48).

Blanc here should be understood in a smaller context as the depositor of the dominant ideology. Les puces may also be symbolic of the widespread corruption, some sort of disease or parasite that has eaten and continues to eat deep into the fabric of the society, paralysing the system that encouraged such corruption and making it impossible to effectively combat the invasion. In the overwhelming situation created by the invasion of the puces, of dominant ideology, the villagers have no choice but to naturalize it even though if it sucks their blood, causes rashes, disrupts their lives and, of course, oppresses them. 
Therborn has suggested elsewhere in his study of ideology and power that to conceive of a text an utterance os ideology is to focus on the way it operates inter formation and transformation of human subjectivity (p. 2). This study does not pretend to be exhaustive since there are many other texts that could be examined similarly. What I have attempted to do is to propose a fresh reading of two recent texts that best capture the reality of the contemporary Cameroonian society. Rather than attempting to define ideology or identify the various characteristics of the concept of ideology, I have sought in this rather preliminary study to understand the process, the mechanism through which ideology forms and transforms children and adult characters. This has been achieved by creating a situation whereby the whole society, as social subjects, produce and reproduce, through their material actions inserted into material practices, (p.169) the communal ideology while simultaneously attempting to de-naturalize the ruling ideology. The change comes about when the characters become aware of what Dennis Mumby has called the process through which meaning systems are structured in society such that particular dominance relations are produced and reproduced.(1) The method of analysis used here go beyond the phraseological plane and the identification of the writer's ideology or ideologies, as has been the case with many studies on ideology. The study analyzes the deep compositional structure of the texts to show how the process of (de)naturalization of ideology for what Terry Castle calls ideological transference has been effected.

\section{Notes}

(1) Mumby is here summarizing the ideas of such cultural theorists as Gramsci, Grossberg, Hall, Larrain and Lukacs.

\section{Works Cited}

Althusser, Louis. "Ideology and Ideological State Apparatuses (Notes towards Investigation)" in Lenin and Philosophy and Other Essays. Trans. Ben Brewster, New York: Monthly Review Press, 1971.

Culler, Jonathan. Structuralist Poetics: Structuralism, Linguistics, and the Study of Literature. Ithaca: Cornell University Press, 1975. 
Dehon, Claire. Le Roman camerounais d'expression française. Birmingham, Al.: Summa Publications, 1989

Duplessis, Blau Rachel. Writing beyond the Ending: Narrative Strategies of Twentieth-Century Women Writers. Bloomington: Iniana University Press, 1985.

Fanon, Frantz. Les Damnés de la terre. Paris: Edition de la Découverte, 1984

Fiske, John. "Britisch Cultural Studies and Television." Channels of Discourse: Teleivision and Contemporary Criticism. Ed. Robert. C. Allen. Chapel Hill: University of Norh Carolina Press, 1987.

Kavanagh, H. James. "Ideology" in Literary Terms for Literary Studies. Eds. Frank Lentricchia and Thomas McLaughlin. Chicago: University of Chicago Press, 1990.

Kom, Ambroise. "Folie et révolution: Sahel! sanglante sécheresse de Mande Alpha Diarra et Les Chauves-souris de Bernard Nanga." in Peuples Noirs/Peuples Africains 37(1984): 89-100.

McGee, Michael. "The 'Ideograph': a Link between Rhetoric and Ideology." Quaterly Journal of Speech 66(1980):1-16.

Mumby, Dennis. "Ideology and the Construction of Meaning: a Communication Perspective," Communication Quaterly 37.4(1989): 291-304.

Nanga, Bernard. Les Chauves-souris Paris: Présence Africaine, 1980. All references are from this edition and page numbers are in parentheses in the text.

Ndachi-Tagne, David. Romanet réalités camerounaises. Paris: L'Harmattan, 1986.

Ndongo, Valentin Les Puces Paris: ABC, 1984. All references are from this edition on page numbers are in parentheses in the text.

Ngara, Emmanuel. Art and Ideology in the African Novel: a Study of the Influence of Marxism on African Writing. London: Heinemann, 1985.

Nkrumah, Kwame. Consciencism: Philosophy and Ideology for Decolonization. New York: Monthly Review Press, 1970

Nzepa, Zacharie. "Idéologie et forme dans Les Chauves-souris de Bernard Nanga Et sur la terre en passant de François Borgia Marie Evembe." Peuples Noirs/Peuples Africains 53/54 (1986): 143-156.

Sutton, F.X. et al. The American Creed quoted in Johnson " Ideology, Art, and Community: African Literature and the Issues." Artist and Audience: African Literature as a Shared Experience. Eds. Richard Priebe and Thomas Hale. Washington D.C.: Three Continent Press \& ALA, 1979. 
Therborn, Gorän. The Ideology of Power and the Power of Ideology. London: NLB, 1980.

Uspensky, Boris. A Poetics of Composition: the Structure of the Artistic Text and the Typology of Comositional Form. Trans. Valentina Zavarin and Susan Witting. Berkeley: University of California Press, 1973.

White, Mimi. "Ideological Analysis and Television." Channels of Discourse: Television and Contemporary Critism. Ed. Robert C. Allen. Chapel Hill: Univerity of North Carolina Press, 1987. 